\title{
AUTORIA NA CRIAÇÃO LITERÁRIA
}

\section{AUTHORSHIP IN LITERARY CREATION}

\author{
Márcia Vescovi Fortunato \\ Instituto Vera Cruz, São Paulo, SP, Brasil
}

\begin{abstract}
Resumo: Este artigo situa as primeiras discussôes sobre autoria enquanto direito de propriedade, apresenta concepçóes que se tornaram referências teóricas pela relevância das discussóes promovidas por seus autores, Bakhtin e Foucault, e, a partir dessas concepçóes e em diálogo com elas, observa de uma perspectiva processual, complementar, a autoria como relaçóes que, no momento da criação, o escritor estabelece com a linguagem, em busca da constituição de si mesmo como autor.
\end{abstract}

Palavras-Chave: Autoria; Bakhtin; Foucault; processo de escrita; representação de si.

Abstract: This article situates the first discussions about authorship as copyright, presents Bakhtin and Foucault's conceptions that became theoretical references by the relevance of their discussions and, from these conceptions and in agreement with them, the article observes from a procedural and complementary perspective, authorship as the relationship that, at the moment of creation, the writer establishes with language, looking for himself or herself as author.

Keywords: Authorship; Bakhtin; Foucault; writing process; representation of self.

\section{Introdução}

O objetivo deste artigo foi retomar e avançar as reflexóes realizadas anteriormente sobre o tema ${ }^{1}$. A prática de ensino no campo e a coordenação do curso de Formaçáo de Escritores do Instituto Vera Cruz (pós-graduaçáo latu senso), desde 2011, conduziram-me a continuar estudando sobre autoria em busca de compreender e aprimorar os métodos de ensino de criaçáo literária. A experiência e a pesquisa demandaram a escrita deste artigo, um pequeno avanço, necessário, que agora clama por continuidade, como toda temática apaixonante com a qual nos envolvemos diretamente. A partir de 2011, voltei mais minha atenção para o campo da criação literária, razão do

\footnotetext{
${ }^{1}$ FORTUNATO, M. V. Autoria e aprendizagem da escrita. 2009. Tese (Doutorado em Educação - Área de concentração: linguagem e educação). Universidade de São Paulo, São Paulo, SP, 2009.

FORTUNATO, M.V. Autoria sob a materialidade do discurso. 2003. Dissertaçáo (Mestrado em Educação - Área de concentração: linguagem e educação). Universidade de São Paulo, São Paulo, SP, 2003.
} 
título e da restrição do tema neste trabalho, uma vez que autoria certamente diz respeito a todo o campo da produçáo escrita.

\section{Autoria como direito}

$\mathrm{Na}$ Idade Média, quando os livros eram ainda manuscritos, os textos de caráter científico deviam receber a assinatura de um autor para ter credibilidade. Era o autor que atribuía valor de verdade a uma obra. Muitos manuscritos dos séculos XIV e XV eram decorados com uma imagem de seu autor em miniatura, como uma marca de autoria (CHARTIER, 1994). Segundo Petrucci (1999), entre os séculos XI e XIV, expandiuse a participação direta do autor na confecção material do livro, seja na redação própria do texto, seja na confecção do livro, e essa prática deu origem à elaboraçáo escrita de textos mais complexos, redigidos parcial ou completamente pelo autor.

Esses são alguns indícios históricos que, segundo Chartier (1994), permitem dizer que datam da Idade Média as primeiras manifestaçôes quanto ao funcionamento da referência ao autor. Foi, porém, com o advento da tipografia que se multiplicaram os livreiros e a produção impressa dos livros e, com eles, surgiram os primeiros instrumentos legais sobre direito autoral.

Até o século XVII, a propriedade literária era concedida a livreiros que detinham direito exclusivo e perpétuo sobre as obras que publicavam. O statute de 1709, na Inglaterra, foi o documento que investiu contra os monopólios dos livreiros londrinos, atribuindo aos autores o direito de eles mesmos pedirem um copyright com duraçáo limitada de 14 anos, a qual poderia ser prorrogada caso o autor ainda estivesse vivo. Foi entáo criada a figura do autor-proprietário.

A França e a Inglaterra não compartilhavam nem as opinióes sobre direitos autorais, nem as concepçóes de "obra literária". Sendo que, na Inglaterra, "os adversários da perpetuidade afirmam que as obras literárias devem ser consideradas como invençóes mecânicas" (CHARTIER, 1994, p. 41), justificando que as obras resultavam de um trabalho e deviam ser submetidas a uma mesma legislaçáo a que estavam submetidos outros produtos. Na França, por sua vez, acreditava-se que "a propriedade literária com limites é injusta - pois as ideias pertencem a todos - e contrária ao progresso das Luzes - pois ela institui o monopólio de um só sobre um saber 
que deve ser um bem comum" (CHARTIER, 1994, p. 41).

$\mathrm{Se}$, sob o ponto de vista inglês, a propriedade incidia sobre o livro e o autor era considerado seu proprietário, para os franceses, as ideias não podiam pertencer a um só e seus direitos só estavam limitados ao interesse público. Os franceses acreditavam que o valor de uma obra estava no seu conteúdo e não na sua forma. Os defensores da propriedade do autor passaram a discutir, então, não o direito sobre as ideias, mas sobre a forma literária como a responsável pela autenticidade da obra, promovendo, assim, uma nova percepção da obra literária.

Como se pode observar, a discussão sobre direitos autorais suscitou uma reflexáo sobre a natureza estética da obra literária e quem ou quais aspectos da obra podem ser responsáveis por seu acabamento singular. Desse modo, o que estava em pauta era um conceito de autoria que não se situava no mesmo plano do conceito de autor-proprietário, mas de sua implicação na obra como criador.

Introduzida no contexto dos conflitos engendrados na Inglarerra pelo statute de 1709, em particular por William Blackstone no processo Tonson versus Collins, em 1760, esse conceito que associa a unicidade da forma, o gênio próprio do autor e a imprescritibilidade da sua propriedade encontra as suas formaçóes mais radicais na polêmica aberta na Alemanha, entre 1773 e 1794, onde, como na França ou na Inglaterra, estão ligadas à discussão sobre os privilégios de livraria e o debate sobre a própria natureza da criação literária. Em meio a essa controvérsia que mobiliza escritores (Zacharias, Becker, Kant, Fichte, Herder), emerge uma nova definição de obra, caracterizada não pelas ideias que ela veicula (que náo podem ser objeto de nenhuma apropriaçáo individual), mas por sua forma - quer dizer, pela maneira particular como o autor produz, reúne, exprime os conceitos que ele apresenta (CHARTIER, 1994, p. 41).

Essa nova percepção da obra literária transcendeu a materialidade do livro, pois a obra adquiriu uma identidade advinda das marcas deixadas no texto pelo autor, subjetivamente. Essa concepçáo de obra prenuncia um novo conceito de autoria, a do autor como princípio de unidade da obra tal como descreveu Foucault em conferência realizada em 1969, intitulada O que é um autor (2006) - ou como imagem ou como voz que se constitui como princípio representador - conforme análise de Bakhtin em notas escritas entre 1959 e 1961, mais precisamente em O problema do texto na linguistica, na filologia e em outras ciências humanas (2003b). 


\section{Autoria: voz ou imagem}

Embora desde a Idade Média se reconheça o autor como o princípio unificador da obra (CHARTIER, 1994), no início do século XX ainda faltava sistematização ao estudo das obras literárias e do papel do autor no processo de criação estética. Em artigo da década de 1920, $O$ autor e a personagem na atividade estética, Bakhtin (2003a) observa a necessidade de uma disciplina que fizesse a abordagem da literatura a partir de princípios coerentes, elegendo o ponto de vista estético em primeiro plano.

Em artigo de 1924, O problema do conteúdo, do material e da forma na criaçâo literária, Bakhtin (2002a) considera a obra literária como produto da transformação sistemática de um conjunto verbal no todo arquitetônico de um evento esteticamente acabado. Esse processo de transformação implica um conteúdo que se origina nos acontecimentos do plano da existência (do real), mas dele é libertado pela forma estética.

Essa forma artística, que é inteiramente realizada no material de que se compóe a obra - no caso da literatura, a língua -, é determinada não só pelo objetivo estético do autor, mas também pela natureza do material. A forma estética, entretanto, não deve ser considerada apenas como "técnica" (BAKHTIN, 2002a, p. 57), justamente porque, por ser forma de um conteúdo, está relacionada axiologicamente com ele. Daí a importância que Bakhtin (2002a) atribui a uma distinção rigorosa entre forma arquitetônica e composicional:

As formas arquitetônicas são as formas dos valores morais e físicos do homem estético, as formas da natureza enquanto seu ambiente, as formas do acontecimento no seu aspecto de vida particular, social, histórica etc.; todas elas são aquisiçôes, realizaçóes, não servem a nada, mas se auto-satisfazem tranquilamente; são as formas da existência estética na sua singularidade. As formas composicionais que organizam o material têm um caráter teleológico, utilitário, como que inquieto, e estão sujeitas a uma avaliação puramente técnica, para determinar quão adequadamente elas realizam a tarefa arquitetônica. A forma arquitetônica determina a escolha da forma composicional: assim, a forma da tragédia (forma do acontecimento, em parte do personagem - o caráter trágico) escolhe a forma composicional adequada - a dramática. Naturalmente, não é por isso que se deva concluir que a forma arquitetônica existe em algum lugar sob um aspecto acabado e que pode ser realizada independente da forma composicional (BAKHTIN, 2002a, p. 25). 
Sem clareza sobre essa distinção, não é possível a correta colocação do problema do estilo, um dos mais importantes da estética, segundo Bakhtin (2002a). Portanto, parece necessário saber como a forma composicional, enquanto organização do material, realiza uma forma arquitetônica, ou seja, unifica e organiza os valores cognitivos e éticos.

$\mathrm{O}$ ato de dar forma estética e axiologicamente significativa a um conteúdo é realizado pelo autor que, nesse processo de construção estética, busca se encontrar, identificando a forma que corporifica seus valores cognitivos e éticos.

Eu devo experimentar a forma como minha relação axiológica ativa com o conteúdo, para prová-la esteticamente: é na forma e pela forma que eu canto, narro, represento, por meio da forma eu expresso meu amor, minha certeza, minha adesão (BAKHTIN, 2002a, p. 58).

A obra de arte, portanto, é resultado de uma atividade intencional do autor, que marca sua posição cognitiva e ética ao dar forma ao conteúdo. $\mathrm{O}$ material adquire forma estética que exprime essas marcas da subjetividade do autor.

O processo de criação, assim, compreende uma sucessão de procedimentos em que se dá a "formatação" do conteúdo sob um meio material - no caso da literatura, são procedimentos de enunciaçáo linguística. O material adquire forma estética e ganha autonomia. Assim, é a forma que atribui às palavras sua condição de enunciado e de objeto da cultura.

Ao isolar um acontecimento do plano empírico e transpor seu conteúdo para um meio sígnico, o autor lhe dá uma determinada forma e, assim, o (re)inventa. $\mathrm{O}$ objeto isolado não coincide mais com o objeto real na unidade da natureza, pois está fora do contexto original. $\mathrm{O}$ isolamento é uma estratégia de autoria que dá início ao processo de criação do objeto estético, cujas relaçôes passam a se dar com a unidade da cultura. Desse modo, a relaçáo dos conteúdos de uma obra com eventos do plano da existência (empírico) se dá por meio de procedimentos de representação.

Em $O$ discurso no romance, escrito por Bakhtin entre 1934 e 1935, esse princípio da representaçáo é retomado. Ao tratar do que torna o romance um objeto plurilinguístico, o autor afirma:

No romance, o homem que fala e sua palavra são objeto tanto de representação verbal como literária. $\mathrm{O}$ discurso do sujeito falante no romance não é apenas transmitido ou reproduzido, mas representado artisticamente e, à diferença 
do drama, representado pelo próprio discurso (do autor) (BAKHTIN, 2002b, p. 135).

É, portanto, o isolamento, a tomada de posse do conteúdo pelo autor e o deslocamento do fragmento do acontecimento do seu contexto original que tornam possível a criaçáo artística. Sendo assim, a principal função da forma é isolar o acontecimento para torná-lo objeto inventado.

A representação tem por objeto não os eventos em si, mas a relação axiológica que o autor mantém com eles. Em O problema do conteúdo, do material e da forma na criação literária (BAKHTIN, 2002a), trabalho publicado em 1924, Bakhtin já pensava esse autor que, em seu processo de criação, exerce a função de inventor ativo do objeto como o autor-criador, elemento da obra, diferente do autor real (ou autor-pessoa), elemento do acontecimento ético e social da vida.

O produto gerado por essa intervenção do autor é resultante de escolhas sígnicas, cognitivas e éticas. Portanto, o autor concentra em seu gesto construtor todas as possibilidades de vir-a-ser da obra, a qual se constitui por meio do autor e vice-versa: o autor-criador constitui-se no ato da criaçáo e deixa no que produz um rastro de si, tornando-se um elemento integrante de sua forma artística. Em sua materialidade estética, a obra é, em relação ao autor, seu meio e seu fim.

Embora aceite a possibilidade de a obra refratar a visão de mundo do autor, Bakhtin não admite comparação meramente factual que confunda o autor-criador com o autor real, pois isso demonstra a incompreensão do princípio criador da relação do autor com a personagem (BAKHTIN, 2003a).

Tal distinção entre autor-criador e autor real é uma proposição recorrente em Bakhtin, apresentada tanto no ensaio $O$ autor e a personagem na atividade estética (BAKHTIN, 2003a), escrito na década de 1920, quanto em seu estudo de Dostoiévski (BAKHTIN, 2005) e, posteriormente, em suas notas de 1959-1961, quando aborda questôes relativas ao texto (BAKHTIN, 2003b):

[...] todo enunciado tem uma espécie de autor, que no próprio enunciado escutamos como o seu criador. Podemos náo saber absolutamente nada sobre o autor real, como ele existe fora do enunciado. As formas dessa autoria real podem ser muito diversas. Uma obra qualquer pode ser produto de um trabalho em equipe, pode ser interpretada como trabalho hereditário de várias geraçóes, etc., e apesar de tudo, sentimos nela uma vontade 
criativa única, uma posição determinada diante da qual se pode reagir dialogicamente. A reação dialógica personifica toda enunciação à qual ela reage (BAKHTIN, 2005, p. 184).

O autor-criador é uma das faces do autor real, pessoa física, que se expressa de um ou outro modo sob a imagem de autor que criou. Nesse sentido, esse autor representado ocupa uma posição determinada no discurso, dirige a cena e reage dialogicamente aos personagens e às situaçóes enquanto cria-os. Para Bakhtin, o autor real não é percebido pelo leitor do enunciado, apenas o autor que ele postula, o autor-criador, por meio do qual se manifesta. Portanto, o autor-criador é uma possibilidade, um devir do autor real.

O conceito de autor torna-se mais claro na medida em que Bakhtin trata o sujeito que ocupa uma posição no enunciado como o autor representado, cuja imagem náo está claramente definida como as demais que cria. $\mathrm{O}$ autor insinua-se na obra, deixa seu rastro, um princípio representador, cuja manifestaçáo (ou posiçáo) pode ser percebida, compreendida, sentida, mas não pode ser delimitada, definida. Uma vez que o autor-criador não coincide com o autor real, é possível reconstituir diferentes imagens de um mesmo autor-criador, a partir da percepção de diferentes posiçóes que ele pode ocupar ao longo do discurso.

Essa imagem do autor, entretanto, mesmo quando representa o autor real, nos discursos narrados em primeira pessoa, ou nos relatos autobiográficos, por exemplo, não deixa de ser uma representação. É um "autor parcialmente representado, mostrado, que integra a obra como parte dela" (BAKHTIN, 2003b, p. 314).

Para compreender melhor o lugar desse autor-criador na obra em relaçáo às personagens e mesmo ao autor real, é interessante atentar para o tratamento dado ao tempo e ao espaço na literatura. Em ", por exemplo, Bakhtin (2002c) analisa a relação entre o tempo e o espaço na literatura, a que chama de cronotopo:

Aqui o tempo condensa-se, comprime-se, torna-se artisticamente visível; o próprio espaço intensifica-se, penetra no movimento do tempo, do enredo e da história. Os índices do tempo transparecem no espaço, e o espaço revestese de sentido e é medido com o tempo. Esse cruzamento de séries e a fusão de sinais caracterizam o cronotopo artístico (BAKHTIN, 2002c, p. 211).

Bakhtin compreende que os gêneros se distinguem pelos diferentes 
cronotopos, criados e interpretados a partir dos cronotopos reais, históricos. Por isso é importante sua análise para os estudos literários. Bakhtin observa também que autores e leitores podem compartilhar os cronotopos representados nos textos, mesmo que se encontrem em tempos e espaços reais diferentes, separados às vezes por séculos e por distâncias espaciais muito grandes.

\begin{abstract}
A obra e o mundo nela representado penetram no mundo real enriquecendo-o, e o mundo real penetra na obra e no mundo representado, tanto no processo de sua criaçấo como no processo subsequente da vida, numa constante renovação da obra e numa percepção criativa dos ouvintesleitores. Esse processo de troca é sem dúvida cronotópico por si só: ele se realiza principalmente num mundo social que se desenvolve historicamente, mas também sem se separar do espaço histórico em mutação. Pode-se mesmo falar de um cronotopo criativo particular, no qual ocorre essa troca da obra com a vida e se realiza a vida particular de uma obra (BAKHTIN, 2002c, p. 359).
\end{abstract}

Em sua análise do romance, Bakhtin analisa o espaço e o tempo do autor e das personagens e observa que o cronotopo do autor-criador não é o mesmo representado na obra de que participam as personagens, nem coincide com o do autor real. Segundo Bakhtin, ele situa-se não exatamente fora dos cronotopos do mundo por ele representado, mas em uma tangente desses cronotopos, uma vez que ele representa o tempo e o espaço como se ele o visse de um ponto de vista mais distante do que o das personagens, por exemplo. Como autor-criador, ele deve mover-se entre os cronotopos representados, ocupando a posição de personagens e do narrador. E, mesmo quando o texto é autobiográfico, Bakhtin (2002c, p. 360) adverte que "como seu criador, ele igualmente permanecerá fora do mundo representado".

Por isso, na obra literária, o discurso do autor não se confunde com o da personagem, mas vai além, já que ultrapassa a dimensão discursiva da personagem e se situa em outro plano, pois o autor, enquanto "consciência criadora", detém mais conhecimento do que a personagem e tem um excedente de visão que torna seu discurso inacessível a ela. Ele colocase na posição de sujeito onisciente (BAKHTIN, 2003a) e onipresente (BAKHTIN, 2002c).

É porque o mundo representado não pode nunca ser cronotopicamente idêntico ao real, que Bakhtin alerta para o uso da expressão "imagem do autor": 
[...] tudo que se tornou imagem numa obra e, consequentemente, ingressou nos seus cronotopos, é criado e nâo criador. "Imagem do autor", caso se compreenda com isso o autor-criador por baixo dela, é uma contradictio in adjecto; toda imagem é algo criado, não criador. Naturalmente, o ouvinteleitor pode criar ele mesmo a imagem do autor (e frequentemente cria-a, ou seja, de alguma forma representa o autor); com isso ele pode utilizar material biográfico e autobiográfico, estudar a época em que o autor vivia e criava, e outros materiais sobre isso. Entretanto ele (o ouvinte-leitor), cria apenas a imagem artístico-histórica, que pode ser mais ou menos verdadeira e profunda, ou seja, subordinada aos critérios que frequentemente são empregados para esse tipo de imagem; mas, naturalmente, ele jamais poderá penetrar na trama figurada da obra (BAKHTIN, 2002c, p. 361).

Essa advertência chama a atenção para três aspectos. Primeiro, ao falar da imagem do autor, em um texto, há referência a uma criação do receptor da obra, portanto, está se falando desse lugar de interlocutor. Segundo, uma vez que é possível a reconstituição dessa representação do autor, durante a recepção da obra, pode-se afirmar que o texto carrega marcas dessa autoria. Terceiro, ao dizer que o receptor pode recorrer a elementos extratextuais que compóem a vida do autor real (biografia, autobiografia, etc.), Bakhtin observa que o autor-criador mantém na obra alguma identidade com o autor real e pode ser compreendido como uma porção desse autor real ou mesmo um desdobramento dele. Portanto, o autor-criador conecta-se em algum ponto ou de alguma maneira com o autor real.

Em síntese, pode-se afirmar que o autor é um princípio representador (BAKHTIN, 2003b) que se deixa perceber não como presença física, mas como uma voz que se insinua e se faz sentir. Falar de autoria é, pois, falar de processo de representação verbal. Qual a relação (ou vínculo) entre o representador e o representado?

Os procedimentos de autoria podem assumir configuraçóes mais complexas quando realizados nos discursos estéticos.

O autor acentua cada particularidade de sua personagem, cada traço seu, cada acontecimento e cada ato de sua vida, os seus pensamentos e sentimentos, da mesma forma como na vida nós respondemos axiologicamente a cada manifestação daqueles que nos rodeiam; na vida, porém, essas respostas são de natureza dispersa, são precisamente respostas a manifestaçôes particulares e náo ao todo do homem, a ele inteiro; [...] Já na obra de arte, a resposta do autor às manifestaçóes isoladas da personagem, se baseiam numa resposta única ao todo da personagem, cujas manifestaçōes particulares são todas importantes para caracterizar esse todo como elemento da obra. É especificamente estética essa resposta ao todo da pessoa-personagem, e 
essa resposta reúne todas as definiçóes e avaliaçôes ético-cognitivas e lhes dá acabamento em um todo concreto-conceitual singular e único e também semântico. Essa resposta total à personagem tem um caráter criador, produtivo e de princípio (BAKHTIN, 2003a, p. 3-4).

O autor, posicionado na obra, dá uma resposta estética à personagem. É interessante observar que essa dialogia é de natureza especial, pois o autor compóe a personagem, acrescenta características, determina gestos e acontecimentos em resposta a um projeto estético que tem em mente.

E é esse acabamento conceitual da personagem que lhe confere uma certa autonomia com relação ao autor, ainda que ela seja inteiramente representada como um elemento da obra e tenha sido totalmente criada pelo autor. A autonomia das personagens na obra é concebida considerando que toda a obra é regida por leis próprias que garantem sua coerência e consistência com relação ao projeto do autor.

Bakhtin define claramente os planos em que se realizam os diálogos: no plano do real, estão o autor real e a obra; no plano da obra, estáo as personagens e a imagem do autor. Entretanto, o discurso do autor real perpassa o discurso das personagens através da imagem de si que projeta na obra e da relação dialógica que esse autor representado estabelece com as personagens. A obra, portadora dessas diversas vozes em diálogo, participa do diálogo real, uma vez que sua unidade e seu sentido são determinados pelo discurso do autor real.

\section{Autoria: posiçáo no discurso}

A concepção de autoria que será exposta neste tópico é produto da leitura da conferência proferida por Foucault (2006), O que é um autor?, apresentada à Societé Française de Philosophie, no Collège de France, em 22 de fevereiro de 1969 e, posteriormente, retomada na aula inaugural proferida no Collège de France, em 2 de dezembro de 1970, sob o título A ordem do discurso (FOUCAULT, 2000).

Qual o interesse de Foucault sobre o tema? No início da conferência O que é um autor?, o filósofo justifica a escolha de seu objeto. Compreende que "[...] a noção de autor constitui o momento crucial da individualização na história das ideias, dos conhecimentos, das literaturas, e também na história da filosofia, e das ciências [...]" (FOUCAULT, 2006, p. 267), por isso a necessidade de revisão do conceito. 
Foucault (2006, p. 265) chama a atenção, também, para o caráter inacabado de sua análise: "Infelizmente, o que lhes trago hoje é muito pouco [...] é um projeto que eu gostaria de submeter a vocês, uma tentativa de análise cujas linhas gerais apenas entrevejo [...]".

A essa advertência soma-se o fato de que é pouco o espaço que tanto uma conferência como uma aula dispóem para o aprofundamento e detalhamento de qualquer reflexão. A partir da leitura do texto, percebe-se que há conceitos que poderiam ser mais explorados, seja pelos diálogos que Foucault estabelecia com outros estudiosos, seja pelo conjunto de ideias que já havia desenvolvido em sua obra e que ancoram sua análise. Esse exercício de leitura, entretanto, não poderia deixar de ser feito, dada a importância do autor e dos conceitos que desenvolve para os estudos de autoria.

"Mas o que há, enfim, de tão perigoso no fato de as pessoas falarem e de seus discursos proliferarem indefinidamente?" (FOUCAULT, 2000, p. 8).

Foi com essa pergunta que Michel Foucault deu início à sua aula inaugural no Collège de France, em 2 de dezembro de 1970, e seu propósito, evidentemente, foi introduzir o tema da aula, a partir da sua posiçáa de sujeito de um discurso que versa sobre a natureza do discurso.

E a resposta que se seguiu foi apresentada como a hipótese que fixava o lugar do trabalho que fazia:

[...] suponho que em toda sociedade a produção do discurso é ao mesmo tempo controlada, selecionada, organizada e redistribuída por certo número de procedimentos que têm por função conjurar seus poderes e perigos, dominar seu acontecimento aleatório, esquivar sua pesada e temível materialidade (FOUCAULT, 2000, p. 8-9).

Essa abordagem rompe com a compreensão do discurso como um produto isolado, descontextualizado da cultura em que é produzido, e questiona a língua como fonte única do sentido. $\mathrm{O}$ discurso como produto da dinâmica social: assim Foucault pontua o fato de que nada do que se diz pode ser compreendido sem serem consideradas as relaçóes que um discurso mantém com outros que circulam, a partir de certas práticas sociais.

Quem fala, fala de um lugar determinado na instituição que o legitima e autoriza. Sustenta sua posição em relaçấo a uma rede de referenciais teóricos, filosóficos ou políticos. Situa-se em determinado momento histórico e fala sob determinadas condiçôes físicas, linguísticas, psicológicas e sociais. E o 
discurso organiza-se sob determinadas normas que fixam um lugar para aquele que fala e que visam a controlar o acontecimento, o acaso.

Uma das tarefas de Foucault foi, portanto, evidenciar alguns desses procedimentos que controlam, selecionam, organizam e redistribuem o discurso e que se dividem entre aqueles que se exercem do exterior do discurso e os procedimentos internos, exercidos pelo próprio discurso. Dentre esses últimos procedimentos está o autor:

$\mathrm{O}$ autor não entendido, é claro, como o indivíduo falante que pronunciou ou escreveu um texto, mas o autor como princípio de agrupamento do discurso, como unidade e origem de suas significaçôes, como foco de sua coerência (FOUCAULT, 2000, p. 26).

Convém deter-se um pouco nessa afirmação. Ao postular essa concepção de autor, Foucault não nega a existência de um autor - indivíduo que articulou ou escreveu o discurso, mas o descreve como aquele que incorpora uma função de autor, que coloca em prática o princípio de autoria previsto em sua cultura (FOUCAULT, 2000). Por isso, em seu livro Arqueologia do Saber, Foucault diferencia o autor - considerado então o indivíduo real que articula ou escreve a frase - do sujeito do enunciado aquele que se constitui no discurso (FOUCAULT, 2002, p. 105).

$\mathrm{O}$ que se pode compreender é que o autor, indivíduo que articula discursos, dispóe de recursos para o exercício da autoria. E, através desses procedimentos, confere unidade ao discurso e autoridade ao sujeito que ocupa o lugar daquele que fala.

O autor é, ao mesmo tempo, uma instância produtora e um princípio de organização e controle do discurso. Enquanto princípio, é uma abstração da função do autor, do indivíduo real que o articulou ou escreveu.

Ao se voltar para o modo de funcionamento da autoria em nossa cultura, Foucault analisa as consequências que a função autor pode acarretar para a constituição do sentido de um texto em diferentes momentos históricos e nos diversos campos discursivos. Ao estabelecer diálogo com os estruturalistas, detém-se especialmente na proposição da "morte do autor", de Barthes (2004), cuja postura teórica é então questionada pelo filósofo.

Em seu artigo $A$ morte do autor, escrito em 1968, Barthes (2004) defende a necessidade de se compreender que o sentido de um texto está em si mesmo, em sua estrutura, e não no autor real, nos seus valores ou nos acontecimentos de sua vida. Barthes é enfático ao rejeitar a ideia de que o 
autor real é a origem do sentido do texto e critica o princípio que determina que o leitor devia depreender de sua leitura o que esse autor quis dizer.

Em $A$ morte do autor, Barthes (2004, p. 59) detecta o contexto da mudança: "apesar do império do Autor ser ainda muito poderoso (a nova crítica muitas vezes não fez mais do que consolidá-lo), é sabido que há muito certos escritores vêm tentando abalá-lo". E cita, então, autores como Mallarmé, Valéry e Proust, que buscaram evidenciar a natureza linguística da literatura e dessacralizar a imagem do autor. E assim nasce o "escriptor" moderno:

O Autor, quando se crê nele, é sempre concebido como o passado de seu livro: o livro e o autor colocam-se por si mesmos numa mesma linha, distribuída como um antes e um depois: considera-se que o Autor nutre o livro, quer dizer que existe antes dele, pensa, sofre, vive por ele; está para sua obra na mesma relação de antecedência que um pai para com o filho. Pelo contrário, o escriptor moderno nasce ao mesmo tempo que seu texto; náo é, de forma alguma dotado de um ser que precedesse ou excedesse a sua escritura, não é em nada o sujeito de que o seu livro fosse o predicado; outro tempo não há senão o da enunciaçăo, e todo o texto é escrito eternamente aqui e agora (BARTHES, 2004, p. 61, grifos do autor).

Barthes opóe à figura do "Autor", autoridade exterior e anterior ao texto e que detém em si mesmo o sentido do texto, a figura do "escriptor", aquele que se projeta em seu texto e vive nele como um construtor que arranja as palavras e assim cria uma estrutura de sentido a ser desvendada na leitura. $\mathrm{O}$ texto é tecido de escritas múltiplas que cabe ao leitor reunir.

É essa autonomia que o pensamento estruturalista atribui à escrita, enquanto objeto da cultura, libertada de seus vínculos com o autor, que Foucault questiona.

Quais as consequências da constatação da "morte do autor"? Para Foucault, há duas noçôes que impedem esse desaparecimento do autor. A primeira delas é que, com a "morte do autor", a crítica passa a buscar na própria obra o seu sentido, o que cria a necessidade de precisar a noção de "obra": é tudo o que o autor escreveu, inclusive os rascunhos, as anotaçóes, as referências? A ausência de uma teoria que desse conta dessa resposta leva Foucault a concluir que "a palavra 'obra' e a unidade que ela designa sáo provavelmente tão problemáticas quanto a individualidade do autor" (FOUCAULT, 2006, p. 270).

Outra noção que Foucault examina é a de escrita: 
A rigor, ela [a escrita] deveria permitir não somente dispensar a referência ao autor, mas dar estatuto à sua nova ausência. No estatuto que se dá atualmente à noção de escrita, não se trata, de fato, nem do gesto de escrever nem da marca (sintoma ou signo) do que alguém teria querido dizer; esforça-se com uma notável profundidade para pensar a condição geral de qualquer texto, a condição ao mesmo tempo do espaço em que ele se dispersa e do tempo em que ele se desenvolve (FOUCAULT, 2006, p. 270).

Essa noção transporta o autor para um anonimato, segundo Foucault, "transcendental", e lhe atribui um caráter sagrado. Se a escrita tem esse poder de fazer esquecer e reprimir, o autor representa o sentido oculto e o princípio crítico das significaçóes implícitas. Desse modo, os privilégios do autor são mantidos sob a salvaguarda do a priori, como pré-condição para a existência do texto.

A proposta de Foucault é então "[...] localizar o espaço assim deixado vago pela desaparição do autor, seguir atentamente a repartição das lacunas e das falhas e espreitar os locais, as funçôes livres que essa desaparição faz aparecer" (FOUCAULT, 2006, p. 271). E, mais à frente, durante debate que se seguiu à conferência "O que é um autor?", o filósofo recoloca sua proposta: "[...] E o que eu tentei analisar é precisamente a maneira pela qual a função autor se exercia, no que se pode chamar de a cultura europeia após o século XVII [...]" (FOUCAULT, 2006, p. 294). E, nessa análise, Foucault observa quatro modos de funcionamento da autoria: insere o discurso no universo jurídico e institucional; atribui ao discurso valor de verdade; determina a origem do sentido do discurso; projeta sujeitos que falam em lugar do autor. É a análise desse último modo de funcionamento que aqui interessa.

Segundo Foucault (2006), os discursos providos da função autor jamais remetem ao autor ou ao seu gesto de escrita. Em lugar desse autor ausente, há sujeitos que falam de lugares distintos e ocupam posiçôes ideológicas e éticas que não correspondem, necessariamente, às posiçôes que o autor ocuparia. O próprio texto traz signos que apontam para o autor: pronomes pessoais, advérbio de tempo e de lugar, a conjugaçáo verbal. Porém, esses elementos náo atuam da mesma forma nos textos providos e desprovidos da função de autor.

Nos providos, como num romance, esses signos nunca remetem para o escritor, nem para o momento em que escreve, nem para seu gesto de escrita, mas para um alter ego que mantém uma distância variável do escritor. "Seria igualmente falso buscar o autor tanto do lado do escritor real quanto 
do lado do locutor fictício; a função autor é efetuada na própria cisão - nessa divisão e nessa distância” (FOUCAULT, 2006, p. 279).

É então que Foucault apresenta o autor como uma função que atribui aos enunciados "egos" distintos, conforme a posiçáo que cada um ocupa em relação ao objeto:

$\mathrm{Na}$ verdade, todos os discursos que possuem a função autor comportam essa pluralidade de ego. O ego que fala no prefácio de um tratado de matemática - e que indica suas circunstâncias da sua composição - não é idêntico nem em sua posição nem em seu funcionamento àquele que fala no curso de uma demonstração e que aparece sob a forma de um "Eu concluo" ou "Eu suponho" [...] Mas se poderia também, no mesmo tratado, observar um terceiro ego; aquele que fala para dizer o sentido do trabalho, os obstáculos encontrados, os resultados obtidos, os problemas que ainda se colocam; [...] em tais discursos, a função autor atua de tal forma que dá lugar à dispersão desses três egos simultâneos (FOUCAULT, 2006, p. 279).

Estabelecendo uma correlação entre a formulação acima e o trabalho A arqueologia do saber (FOUCAULT, 2002), é possível ler esses diferentes "egos" como sujeitos do enunciado, desdobramentos de um autor que se coloca em diferentes posiçôes, de acordo com as restriçôes do discurso e suas intenções de comunicação.

Nessa obra, publicada no mesmo ano de 1969, Foucault deixa clara a distinção entre autor e sujeito do enunciado:

\footnotetext{
Para que uma série de signos exista, é preciso - segundo o sistema das causalidades - um "autor" ou uma instância produtora. Mas esse "autor" náo é idêntico ao sujeito do enunciado; e a relação de produçấo que mantém com a formulação não pode ser superposta à relação que une o sujeito enunciante e o que ele enuncia (FOUCAULT, 2002, p. 105-106).
}

Nesse mesmo contexto, Foucault trata das inúmeras possibilidades de formulação de diferentes sujeitos na obra literária. Elege o romance para refletir sobre as particularidades desse gênero, composto por enunciados diversos que implicam diferentes posiçóes, portanto diferentes sujeitos - os fragmentos de diálogos e os pensamentos das personagens, os textos publicados sob pseudônimo -, e comenta a dificuldade que essa multiplicidade de sujeitos pode representar para os que querem relacionar todas essas formulaçōes ao autor [real] do texto, ao que ele queria dizer, o que pensava etc. Foucault conclui que em todas essas circunstâncias o autor 
[real] não é idêntico aos sujeitos dos enunciados (FOUCAULT, 2002).

A reflexáo vai além em $\mathbf{A}$ arqueologia do saber, quando Foucault (2002) observa que se poderia pensar que essa ausência do autor fosse uma particularidade da literatura, mas não, esse procedimento é absolutamente geral, uma vez que o sujeito do enunciado, embora seja uma função determinada, não se mantém necessariamente a mesma de um enunciado a outro. E conclui: “[...] um mesmo indivíduo pode ocupar alternadamente, em uma série de enunciados, diferentes posiçôes e assumir o papel de diferentes sujeitos" (FOUCAULT, 2002, p. 107).

No tratado de Matemática, exemplo citado acima, extraído da conferência "O que é um autor?" (FOUCAULT, 2006), há diferentes sujeitos; e cada sujeito tem um papel a desempenhar no discurso em questão. Porém, nenhuma dessas posiçóes podem ser identificadas com o autor real, ou todas o representam, considerando-se que todos esses sujeitos são desdobramentos do mesmo autor.

Em sua aula inaugural no Collège de France, em 1970, A ordem do discurso (FOUCAULT, 2000), ao considerar o autor princípio de agrupamento, unidade de origem e foco de coerência do discurso, Foucault reafirma a possibilidade de discursos que não recebem seu sentido de um autor:

[...] existem, ao nosso redor, muitos discursos que circulam, sem receber seu sentido ou eficácia de um autor ao qual seriam atribuídos: conversas cotidianas, logo apagadas; decretos ou contratos, que precisam de signatários e não de autor; receitas técnicas transmitidas no anonimato (FOUCAULT, 2000, p. 26).

Para compreender melhor essa proposição, é interessante examinar o que Foucault observa em $\mathbf{A}$ arqueologia do saber:

Não é preciso, pois, conceber o sujeito do enunciado como idêntico ao autor da formulaçăo, nem substancialmente, nem funcionalmente. Ele não é, na verdade, causa, origem ou ponto de partida do fenômeno da articulaçáo escrita ou oral de uma frase; não é, tampouco, a intenção significativa que, invadindo silenciosamente o terreno das palavras, as ordena como o corpo visível de sua intuição; não é o núcleo constante, imóvel e idêntico a si mesmo de uma série de operaçóes que os enunciados, cada um por sua vez, viriam manifestar na superfície do discurso. É um lugar determinado e vazio que pode ser efetivamente ocupado por indivíduos diferentes; mas esse lugar, em vez de ser definido de uma vez por todas e de se manter uniforme ao 
longo de um texto, de um livro ou de uma obra, varia - ou melhor, é variável o bastante para poder continuar, idêntico a si mesmo, através de várias frases, bem como para se modificar a cada uma. Esse lugar é uma dimensão que caracteriza toda formulação enquanto enunciado, constituindo um dos traços que pertencem exclusivamente à funçáo enunciativa e permitem descrevê-la. Se uma proposição, uma frase, um conjunto de signos podem ser considerados "enunciados", não é porque houve, um dia, alguém para proferi-los ou para depositar, em algum lugar, seu traço provisório; mas sim na medida em que pode ser assinalada a posiçáo do sujeito. Descrever uma formulação enquanto enunciado não consiste em analisar as relaçóes entre o autor e o que ele disse (ou quis dizer, ou disse sem querer); mas em determinar qual é a posiçāo que pode e deve ocupar todo indivíduo para ser seu sujeito (FOUCAULT, 2002, p. 109, grifo nosso).

Enunciado, para Foucault, define-se na perspectiva discursiva, ou seja, no âmbito do uso social da linguagem. Portanto, a constituição do sujeito é uma das condições para existência do enunciado. A constituição de sujeitos do enunciado é, entáo, um procedimento de autoria que envolve a representação daquele que ocupa o lugar de quem fala.

Se a ausência do autor [real] e a consequente constituição de sujeitos dos enunciados é procedimento geral nos discursos, qualquer que seja o gênero, como compreender a existência de discursos desprovidos da função autor? Como sustentar que o suposto locutor real a que remete uma carta pessoal coincide com o autor real, pessoa física, que redigiu a carta e a assinou? Será que qualquer autor, ao produzir um discurso, mesmo tendo a pretensão de colocar a si próprio na posição de sujeito do discurso, não estará ocupando uma posiçấo entre as muitas que poderia ocupar? Será que é possível representar em um discurso o autor em sua totalidade de indivíduo do mundo empírico? Será que a parcela do indivíduo passível de representação sustenta o indivíduo em sua totalidade?

Em resposta a essas questóes, é possível pensar que, ainda que os discursos sejam díspares quanto à forma de sua composição e quanto à natureza da funçáo autor, todos resultam de procedimentos de autoria. $\mathrm{O}$ próprio apagamento do autor é um procedimento de autoria. Portanto, se o formulário de imposto de renda é suficientemente impessoal para não deixar transparecer as marcas de sua autoria, ainda assim haverá um autor, cujo procedimento foi exatamente apagar seus rastros (marcas de estilo, por exemplo). Se uma carta pessoal é razoavelmente bem-sucedida na representação de um sujeito que coincide, ainda que parcialmente, com o autor real, ela é portadora da função autor cuja característica foi o locutor 
real ocupar o lugar determinado e vazio para ser o sujeito.

O que Foucault parece fazer compreender, entretanto, é que o conteúdo de um formulário de imposto de renda ou de uma carta pessoal remete o leitor para o contexto real de vida do autor. Esses discursos são desprovidos da função autor que consiste em constituir sujeitos para ocupar as diferentes posiçóes previstas para ele. Ou simplesmente: há discursos em que a função autor não atua de modo a dar lugar à dispersão de sujeitos.

Sobre os discursos desprovidos da função autor, ao final da conferência, em resposta a L. Goldman, o filósofo afirmou:

[...] não disse que o autor não existia; eu não disse e estou surpreso que meu discurso tenha sido usado para um tal contra-senso. Retomemos um pouco tudo isso. Falei de uma certa temática que se pode localizar tanto nas obras como na crítica, que é, se vocês querem: o autor deve se apagar ou ser apagado em proveito das formas próprias ao discurso. Isto posto, a pergunta que eu me fazia era a seguinte: o que essa regra do desaparecimento do escritor ou do autor permite descobrir? Ela permite descobrir o jogo da função autor. E o que eu tentei analisar é precisamente a maneira pela qual a funçáo autor se exercia, no que se pode chamar de a cultura européia após o século XVII. Eu o fiz, certamente, de maneira muito geral, e de uma forma que eu gostaria que fosse bem mais abstrata, porque se tratava de uma ordenaçãao do conjunto. Definir de que maneira se exerce essa função, em que condições, em que campo etc., isso não significa, convenhamos, dizer que o autor não existe (FOUCAULT, 2006, p. 294).

Assim, ao descrever quatro características da função autor, Foucault enumera as condições de existência da função autor nos discursos. As variáveis que definem o discurso também vão incidir sobre os ajustes e a modalização da função autor em cada discurso. Com essa última característica, Foucault fixa um lugar para o autor no discurso: ele vai ocupar uma ou mais posiçóes de sujeito do discurso e só pode ser depreendido, conhecido ou reconhecido a partir da atividade discursiva.

Agora, entáo, talvez possa ser compreendida melhor essa característica da função autor: "[...] ela não remete pura e simplesmente a um indivíduo real, ela pode dar lugar simultaneamente a vários egos, a várias posiçôessujeitos que classes diferentes de indivíduos podem vir a ocupar" (FOUCAULT, 2006, p. 279-280).

\section{Autoria: relaçáo com a linguagem}


Numa perspectiva histórica, a primeira grande discussão relativa à autoria trata do reconhecimento da propriedade da obra e, portanto, do estabelecimento da identidade de direito do autor, legalmente definida. Essa discussáo deu origem a outra, acerca do que estava em jogo, se a ideia ou a forma do texto. $\mathrm{O}$ resultado dessa polêmica foi a compreensáo de que a autoria se atribuía ao formato da obra, tal como concebida pelo escritor. Ficou claro, assim, que o texto escrito era o objeto de propriedade, como até hoje. Esse debate acabou gerando a necessidade de estudos sobre estilo e estética textual, em busca de observar como o autor manifesta-se no texto.

Com os estudos de Bakhtin, a discussão centrou-se na perspectiva da teoria literária ou da criação da estética. A autoria foi analisada no âmbito do reconhecimento da singularidade das marcas textuais que, como rastros, insinuam um autor, tal qual uma voz ou uma imagem que dá unidade ao texto e, ao mesmo tempo, se constitui no texto, como princípio representador.

$\mathrm{Na}$ perspectiva de Foucault, a autoria foi vista como função que dá unidade ao discurso. O autor, para Foucault, é o sujeito que ocupa uma posiçấo discursiva. Essa concepção, em sintonia com a análise do discurso, está voltada para a consideração do contexto histórico e ideológico a partir dos quais os discursos são enunciados ou escritos. Foucault, assim como Bakhtin, diferencia o autor [real] do sujeito discursivo, assinalando que este último pode assumir diferentes posiçóes num mesmo discurso e que nunca coincide totalmente com o autor [real].

O objeto de estudo para Bakhtin eram obras acabadas:

Estamos interessados primordialmente nas formas concretas dos textos e nas condiçōes da vida concreta dos textos, na sua inter-relação e interação (BAKHTIN, 2003b, p. 319).

Bakhtin, assim como Foucault, reconhecia o autor como princípio organizador da obra e o texto como seu lugar de existência. A autoria, ou a marca do autor, nesse sentido, é passível de descrição e análise. Por outro lado, tanto o entendimento da autoria enquanto posiçáo ou lugar de fala, como o de imagem ou voz, que emerge do texto marcado por um estilo pessoal do autor, são produtos de uma atividade autoral e, no momento em que são percebidos no texto, são atos passados, acabados, por isso produtos.

Fazendo o exercício de pensar a autoria não como produto, já que ela é gestada muito antes, na concepção da obra, pode-se pensar um pouco mais a autoria como processo. Para efeito de clareza, a partir de agora, o autor real 
será referido como escritor e o autor constituído pelo texto e nele manifesto será referido como autor, entendendo que este resulta da atividade criadora daquele.

A partir de agora, far-se-á referência ao escritor porque, em se tratando do processo de criação, supóe-se um gradativo deslizamento de posição do escritor para o autor, conforme a obra é criada. A autoria constrói-se enquanto o escritor escreve, revisa, reescreve e também quando recorre à memória, à pesquisa e a todos os gestos que se conectam à sua obra.

A questáo que se pode colocar então é: considerando o processo de construção de uma obra, a autoria não é também construída pouco a pouco, conforme a obra constitui-se? Supondo que a resposta a essa questáo seja sim, como desenvolve-se esse processo?

A hipótese aqui defendida é a de que a relação do escritor com linguagem constitui o ato ou o movimento de autoria. $\mathrm{O}$ escritor gera sentido ao articular linguagem, conectando palavras e enunciados a verdades ou princípios que potencialmente organizam o todo da obra. Como esse movimento é dinâmico, esses princípios ou verdades podem alterar-se no trajeto de criação, assim como pode alterar-se a relação pessoal e única do escritor com o mundo: experiências de vida, conhecimentos, memória e saberes oriundos da relação com discursos com os quais convive.

Bakhtin refere-se à posição ativa do autor na construção da obra e propóe que, uma vez que sujeitos e eventos se tornam expressão semiótica (BAKHTIN, 2003b), o conteúdo de uma obra não pode ser apreendido fora dela. E é por isso que a forma arquitetônica não pode ser apreendida isoladamente da forma composicional. O texto é um objeto construído e a linguagem é a ferramenta que possibilita sua construçáo.

Em consonância com o entendimento de Bakhtin, Bronckart (2003) compreende a linguagem humana como atos de interação associados a eventos sociais, constituindo, portanto, uma característica da atividade social humana, que se materializa com a semiotização das relaçôes do indivíduo com o meio:

As representaçóes semiotizadas são, em outros termos, os produtos de uma "colocação em interface" de representaçóes individuais e coletivas. Essa semiotização introduz, além disso, uma distância nas relaçôes que os organismos humanos mantêm com o meio; este não é mais a única instância de controle das representaçôes. Essa distância, por sua vez, torna possível a autonomizaçáo das próprias produçōes semióticas. Elas podem, a partir daí, organizar-se em uma atividade particular, que continua, claro, em 
interdependência com as outras atividades da espécie, mas que se configura em organizaçôes de signos dotados de uma autonomia parcial. Assim, a semiotizaçáo dá lugar ao nascimento de uma atividade que é propriamente de linguagem e que se organiza em discursos ou em textos. Sob o efeito da diversificação das atividades não verbais [non langagières] com os quais esses textos estão em interação, eles mesmos diversificam-se em gêneros (BRONCKART, 2003, p. 35, grifos do autor).

Essa percepção das atividades de linguagem como parte de eventos sociais mais amplos que envolvem não só as representaçôes semióticas textuais, mas ações, acontecimentos, fatos em razão dos quais a linguagem atua, funciona, representa, sustenta uma visão de mundo, constitui a noção que se pretende considerar aqui como ponto de partida.

Tomar o texto como objeto que participa de uma extensa rede de relaçóes sociais e semióticas é compreender o autor como sujeito que articula essas relaçóes e, portanto, que deve dominar não apenas conhecimento sobre o código linguístico, mas sobretudo das práticas sociais em que está envolvido e os sistemas semióticos correlacionados ao objeto que produz. É nesse sentido que se pode entender a noção de autoria como princípio de organizaçáo e controle do discurso a que se refere Foucault (2000), colocação que deixa clara a existência de uma atividade autoral enquanto processo de escrita.

Se a literatura for compreendida como uma forma de ver e compreender o mundo, os indivíduos e suas manifestaçóes, ou mesmo como um modo de autoconhecimento, ou conhecimento do outro e sua cultura, pode-se dizer que a obra literária é uma resposta estética que o escritor formula diante das incontáveis questóes e problemas que o mundo ou a vida lhe colocam. E, assim sendo, ainda que seja entendida sem nenhum compromisso com a verdade, que seja apenas uma expressão estética subjetiva, a literatura será produto de uma atividade autoral que se define pela relação entre escritor e seu objeto.

O escritor constrói o texto como interface dessa relação. Seu objeto são as palavras. É dessa fonte de sentido de que nasce a obra. O texto - com suas marcas e a posição de que fala o autor - resulta de decisóes tomadas no ato de criação, portanto, antes do texto acabado, e só se torna visível quando a obra está feita, acontecida, e o ato de autoria está finito.

Decisôes sobre o acabamento formal do texto são gestos de autoria a partir de escolhas orientadas pelo projeto arquitetônico da obra; e esse projeto é formatado axiológica e esteticamente por todas as conexóes 
que o escritor faz entre seu mundo interior e representaçóes da realidade. Desse modo, o autor é constituído a partir das decisóes que fazem dele o organizador desse discurso. É justamente sobre esse ponto de virada - em que o escritor dá lugar ao autor - que algumas reflexôes serão aqui tecidas. Para isso, recorrer-se-á a alguns estudos do processo cognitivo de escrita e da criação literária.

Flower e Hayes (1981), pesquisadores no campo da retórica cognitiva, constataram que os escritores estabelecem objetivos para o texto que estão escrevendo. Embora seja frequente um escritor ter que gerar um objetivo específico para seu texto, também é certo que muitas vezes recorre a objetivos que já estão estocados em sua memória, que são principalmente aqueles mais básicos e genéricos, utilizados sem nem mesmo ter consciência do que está sendo mobilizado, por exemplo: "interessar o leitor", "iniciar pela introdução".

Durante o processo de escrita, escritores também elaboram uma rede de objetivos secundários que especificam e definem os objetivos mais amplos e mais gerais, hierarquicamente superiores. Nessa tarefa, os escritores reformulam os objetivos iniciais ou criam objetivos secundários, muitas vezes influenciados pelo que aprenderam no próprio exercício da escrita (FLOWER; HAYES, 1981).

Para Flower e Hayes (1981), o ajuste, a decomposição e a reformulação de objetivos constituem um poderoso processo criativo. Observando como ocorrem a geraçáo e consolidaçáo de ideias, a reformulação e o desdobramento de objetivos, pode-se ver o processo de escrita ocorrendo. E pode-se compreender, entáo, porque esse processo de produção de textos tem um efeito tão amplo no produto escrito, pois é por meio dele que o texto escrito se constitui. Essa rede de objetivos que o escritor constrói e desconstrói o tempo todo é motivada por relaçóes que ele estabelece não só entre o tópico que está desenvolvendo e o texto já escrito, como também com elementos de sua memória. O conhecimento sobre algum tópico tornase mais consciente e confiável à medida que se busca na memória ideias correlatas.

Perl (1980) descreve movimentos recursivos que o escritor desenvolve enquanto escreve. Assim como Flower e Hayes (1981), a pesquisadora entende que o processo de escrita é recursivo e não linear como uma sequência planejar - escrever - revisar. Ser recursivo significa que existe um movimento de escrita para frente pelo fato de ter existido outro para trás. Por exemplo, é frequente o escritor reler partes do texto já escrito antes de 
prosseguir com a escrita, ou seja, a leitura do texto foi um movimento para trás, para o texto já escrito, o que gerou novas ideias para dar sequência à escrita, o movimento para frente. Também é frequente o escritor retomar o tópico ou ideia original para gerar novas ideias e continuar a escrever.

O processo recursivo mais peculiar que Perl (1980) descreve trata da conexáo que o escritor pode estabelecer consigo mesmo ao recorrer à memória das experiências sensoriais:

There is also a third backward movement in writing, one that is not so easy to document. It is not easy because the move, itself, cannot immediately be identified with words. In fact, the move is not to any words on the page nor to the topic but to feelings or non-verbalized perceptions that surround the words, or to what the words already present evoke in the writer. The move draws on sense experience, and it can be observed if one pays close attention to what happens when writers pause and seem to listen or otherwise react to what is inside of them. The move occurs inside the writer, to what is physically felt. The term used to describe this focus of writers' attention is felt sense. The term "felt sense" has been coined and described by Eugene Gendlin, a philosopher at the University of Chicago. In his words, felt sense is the soft underbelly of thought.... a kind of bodily awareness that . . . can be used as a tool ... a bodily awareness that ... encompasses everything you feel and know about a given subject at a given time. . It is felt in the body, yet it has meanings. It is body and mind before they are split apart ${ }^{2}$

O escritor, nesse movimento, tem sua memória ativada por um acaso e, de uma relação que acaba de estabelecer, surge uma ideia que conecta o texto a seu autor intimamente. É quando essa percepção ganha sentido e forma. Não seria o felt sense o que, no meio literário, é conhecido como

\footnotetext{
${ }^{2}$ Há ainda um terceiro movimento "para trás" na escrita. Este não é tâo fácil de registrar. Não é fácil porque o movimento em si mesmo não é imediatamente identificado com palavras. $\mathrm{Na}$ verdade, o movimento não está ligado a nenhuma palavra na página, nem ao tópico, mas a sentimentos ou percepçôes nâo verbalizados que circundam as palavras, ou àquilo que as palavras já escritas evocam no escritor. Este movimento se baseia em experiência sensorial e pode ser observado se prestarmos especial atençáo ao que acontece quando escritores fazem pausas e parecem escutar ou mesmo reagir ao que está dentro de si. O movimento acontece no interior do escritor e é sentido fisicamente. $\mathrm{O}$ termo usado para descrever esse foco da atenção do escritor é senso-percepção [sensaçáo percebida, percepção sentida - felt sense]. O termo felt sense foi cunhado e descrito por Eugene Gendlin, um filósofo da Universidade de Chicago. Em suas palavras, felt sense é o ponto fraco do pensamento... um tipo de despertar da consciência corpórea... pode ser usado como uma ferramenta... uma consciência corporal que... engloba tudo o que você sente e sabe sobre um dado assunto num dado momento... é sentido no corpo, e ainda assim tem significados. É corpo e mente antes de serem apartados. (Tradução de Deborah Dornelles).
} 
"inspiração"? Pode-se entender que sim. E posto desse modo, a inspiração não é um sentido que chega ao escritor de fora para dentro, como uma iluminação recebida, ao contrário, configura-se como um retorno a si mesmo.

O processo recursivo assim descrito como um movimento interior, que estabelece conexão entre elementos sensoriais da memória e provoca resposta corporal, parece o ato mais típico para ilustrar como podem ser subjetivas e abstratas as relaçôes de autoria.

Essa proposição talvez capte um importante movimento de autoria. Pode-se supor que a voz ou a imagem a que se refere Bakhtin ou a função autor ou posiçáa do sujeito de que fala Foucault coincidam com movimentos de felt sense: por isso a subjetividade e a abstração das relações de autoria. Seu resultado pode ser identificado no texto, mas o momento mesmo da concepçáo autoral da obra talvez seja algo difícil de capturar, já que os objetivos do escritor tomam corpo na voz do autor.

Em 1934, Vygotsky (1987), em seu estudo sobre a relação entre pensamento e linguagem, afirmou:

O pensamento, ao contrário da fala, náo consiste em unidades separadas. Quando desejo comunicar o pensamento de que hoje vi um menino descalço, de camisa azul, correndo rua abaixo, náo vejo cada aspecto isoladamente: o menino, a camisa, a cor azul, a sua corrida, a ausência de sapatos. Concebo tudo isso em um só pensamento, mas expresso-o em palavras separadas. Um interlocutor em geral leva vários minutos para manifestar um pensamento. Em sua mente, o pensamento está presente em sua totalidade e num só momento, mas na fala tem que ser desenvolvido em uma sequência. Um pensamento pode ser comparado a uma nuvem descarregando uma chuva de palavras. Exatamente porque um pensamento não tem um equivalente imediato em palavras, a transiçáo do pensamento para a palavra passa pelo significado (VYGOTSKY, 1987, p. 128-129).

A imagem da nuvem e da chuva de palavras que Vygotsky usou ilustra bem a articulação do pensamento em linguagem. O movimento de felt sense também sofre essa transformação quando o escritor, a partir de uma conexão profunda com seu universo interior, gera ideias, traduzidas em palavras, ao que deseja comunicar. Nesse sentido, o processo de criação literária consiste essencialmente nas relaçóes que o escritor estabelece com a linguagem e, se a linguagem dá forma ao pensamento, ela também o estrutura. Desse ponto de vista, a obra é o pensamento organizado e estruturado pela linguagem. A atividade de autoria consiste nesse movimento de articulação. $\mathrm{O}$ objeto do 
escritor é a palavra.

Em seu estudo The cognition of discovery: defining a rhetorical problem, de 1980, Flower e Hayes (1994) consideram a escrita de textos uma atividade de resolução de problemas. Para esses pesquisadores, resolver um problema envolve a "descoberta" de uma solução, mas não se trata de encontra uma solução que está pronta e só precisa ser resgatada. Ao contrário, resolver um problema implica, durante a operação de escrita de um texto, a mobilização de muitas habilidades em busca da construção de respostas. E, embora sempre envolva procedimentos exploratórios abertos - escrita livre ou devaneios, esse processo não é acidental.

O processo de escrita pode entáo ser descrito como um conjunto de demandas ou problemas retóricos que o escritor tem para solucionar. Dentre os diversos movimentos de construção da resposta a esses problemas, ocorre o movimento de felt sense e a construção do sentido a partir da articulação do texto. Outros movimentos decorrem dessa primeira construçáo, como a revisão, a geração de novas ideias ou a atividade de monitoramento que o escritor pode fazer do texto já escrito. Entretanto, parece que são os movimentos de felt sense que promovem mais intensamente a construção de respostas para resolução de problemas de autoria. Eles parecem funcionar como atividades cognitivas hierarquicamente superiores a partir das quais outras acontecem, pois é em função das redes de sentido que uma obra se desenvolve.

\section{Conclusáo}

$\mathrm{O}$ que foi feito até aqui representa um esforço de clarear uma perspectiva de observação da autoria que até então, em meus trabalhos anteriores, não havia ficado claro, apesar de estar sugerido em meus estudos sobre o processo de escrita. A intenção era sistematizar a reflexáo que estava em curso e sugerir novas possibilidades de pesquisa sobre autoria no campo da criação literária. A expectativa é ter contribuído para que se possa ampliar e aprofundar a perspectiva processual do conceito de autoria e motivar outros pesquisadores a ampliar investigações nesse campo de estudo. 


\section{Referências}

BAKHTIN, M. O problema do conteúdo, do material e da forma na criação literária. In: BAKHTIN, M. Questóes de literatura e de estética. A teoria do romance. Tradução Aurora Fornoni Bernardini et al. 5. ed. São Paulo: Hucitec, 2002a, p. 13-70.

. O discurso no romance. In: BAKHTIN, M. Questóes de literatura e de estética. A teoria do romance. Tradução Aurora Fornoni Bernardini et al. 5. ed. São Paulo: Hucitec, 2002b, p. 71-210.

Formas de tempo e de cronotopo no romance. In: BAKHTIN, M. Questóes de literatura e de estética. A teoria do romance. Tradução Aurora Fornoni Bernardini et al. 5. ed. São Paulo: Hucitec, 2002c, p. 211-362.

. O autor e a personagem na atividade estética. In: BAKHTIN, M. Estética da criaçáo verbal. Tradução Paulo Bezerra. São Paulo: Martins Fontes, 2003a, p. 3-192. [Original russo, 1920-1930].

. O problema do texto na linguística, na filologia e em outras ciências humanas. In: BAKHTIN, M. Estética da criação verbal. Tradução Paulo Bezerra. São Paulo: Martins Fontes, 2003b, p.307-335.

Problemas da poética de Dostoiévski. Tradução Paulo Bezerra. Rio de Janeiro: Forense Universitária, 2005.

BARTHES, R. O Rumor da língua. Tradução Mario Laranjeira. São Paulo: Martins Fontes, 2004.

BRONCKART, J-P. Atividade de linguagem, textos e discursos: por um interacionismo sócio-discursivo. Tradução Anna Rachel Machado e Péricles Cunha. São Paulo: EDUC, 2003. 
CHARTIER, R. A ordem dos livros. Tradução Mary Del Priore. Brasília: UNB, 1994.

FLOWER, L.; HAYES, J. R. Uma teoria do processo cognitivo da escrita. Revera - estudos de criação literária do Instituto Vera Cruz. v.1, n. 1, p. 37-68, 2016. Disponível em: <http://site.veracruz.edu.br/instituto/revera/ index.php/revera>. Acesso em: 27 ago. 2018.

A Cognitive Process Theory of Writing. College Composition and Communication, v. 32, n. 4. p. 365-387, dez. 1981.

. The cognition of discovery: defining a rhetorical problem. In: PERL, S. (Org.). Writing Process. Davis (CA, USA): Hermagoras, 1994, p. 63-74.

FOUCAULT, M. A Ordem do Discurso. Tradução Laura Fraga de Almeida Sampaio. 5. ed. São Paulo: Loyola, 2000.

A Arqueologia do Saber. Tradução Luiz Felipe Baeta Neves. 6. ed. Rio de Janeiro: Forense Universitária, 2002.

. O que é um autor?. In: FOUCAULT, M. Estética: Literatura e Pintura, Música e Cinema. Organização e seleção de textos Manoel Barros da Motta. Tradução Inês Autran Dourado Barbosa. 2. ed. Rio de Janeiro: Forense Universitária, 2006, p. 264 [Ditos e Escritos, vol 3].

LEVY, M. C.; RANSDELL, S. Writing Signatures. In: The science of writing: theories, methods, individual differences and applications. Mahwah (NJ, EUA): Lawrence Erbaum Associates, 1996, p. 149-161.

PERL, S. Understanding Composing. College Composition and Communication, USA, v. 31, v. 32, p. 363-369, 1980.

PETRUCCI, A. Alfabetismo, escritura, sociedad. Barcelona: Gedisa, 1999. 
VYGOTSKY, L.S. Pensamento e Linguagem. Tradução Jeferson Luiz Camargo, Martins Fontes, 1987.

Recebido: 02/04/2018

Aceito: $16 / 08 / 2018$

DOI - http://dx.doi.org/10.5902/2179219431983 